\title{
PROOF OF CONCEPT TESTING OF THE ADVANCED NOXSO FLUE GAS CLEANUP PROCESS
}

\author{
CONTRACT NUMBER: DE-AC22-89PC88889
}

Quarterly Technical Progress Report for the Period July 1 - September 30, 1990

Prepared by: Robert L. Gilbert, Program Manager DOE Project Manager: Diane Revay Madden

$\begin{array}{llll}1.0 & \text { INTRODUCTION AND SUMALARY DE91 } 004217\end{array}$

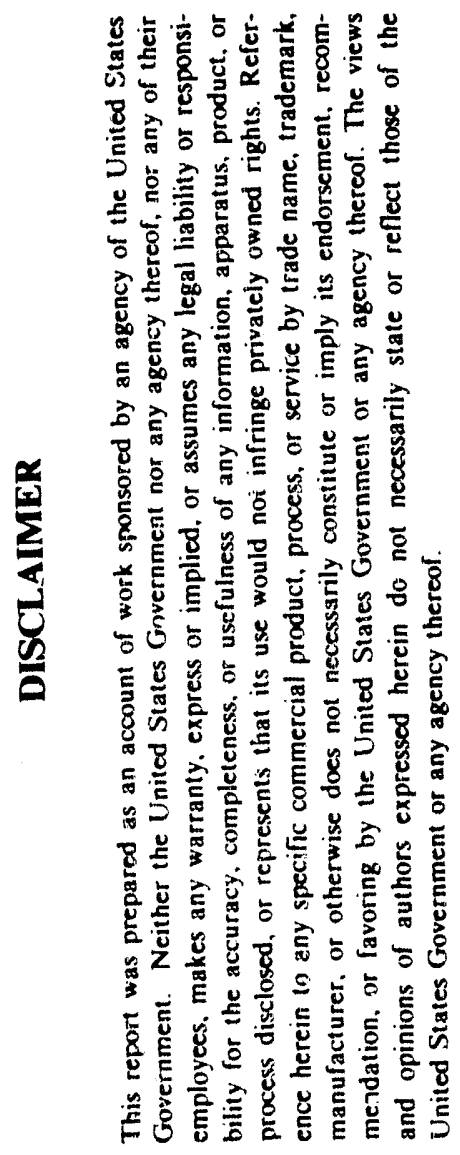

This project is being performed by MK-Ferguson, for the U.S. Department of Energy Pittsburgh Energy Technology Center. The project is a pilot plant scale-up from laboratory testing of the NoXSO flue gas cleanup process. The process simultaneously removes both sulfur and nitrogen oxides from the flue gas.

The objective of this project is to demonstrate that the NOXSO Process can achieve the $\mathrm{SO}_{2}$ and $\mathrm{NO}_{x}$ removal efficiencies under field conditiohs required for application to coal-fired utility boilers.

The pilot plant, will be built at onio Edison's Toronto station, a coal-fired power piant in Toronto, ohio. It will process a 12,000-SCFM slip stream of flue gas from the power plant.

The project is divided into six tasks. Task 1 establishes the work plan that details all the activities related to the successful completion of the project. Task 2 consists of the design and construction of the pilot plant. Task 3 consists of an experimental program to define both operating conditions and performance data to support Task 4 . Task 4 primary activities are to conduct a long-duration test which attains continuous $90 \%$ sulfur dioxide and nitrogen oxide removal rates. Task 5 is the conceptual design of a 500-MW plant, including an economic evaluation of the conceptual design. Task 6 is the demolition of the pilot plant and restoration of the site. 
The objective of this project is to demonstrate the potential for application of the Noxso Flue Gas Treatment (FGT) technology to coal-fired utility boilers in the 1990s. To accomplish this, the Noxso team will design, construct, operate, and test a proof-of-concept scale NoxSo test facility at Ohio Edison's Toronto Station. The goal of the proof-of-concept test is to obtain the engineering data required to prepare a costeffective design of a commercial scale Noxso process module at an acceptable level of technical risk. A secondary goal of the test program is to optimize process performance, i.e., achieve $90 \%$ removal of $\mathrm{SO}_{2}$ and $\mathrm{NO}_{4}$ from the flue gas at the lowest possible cost, $x$ while maintaining the high level of system reliability dictated by the utility market.

\subsection{PROJECT OVERVIEW}

The dynamic modeling tests were completed this quarter with the finalization of the J-valve design.

The detailed engineering Task 2.3 was 958 complete through september 30th. Engineering completed the detailed design this quarter. The balance of the engineering effort will be construction and start-up support.

The earthwork and foundation work was completed. The structural steel subcontractor started work and the piping and electrical work was started as well.

\subsection{DYNAMIC MODELING TESTS}

PEMM-Corp. modeling tests commenced in April and continued in this quarter. The modeling effort focused on developing the J-valve design model to operate over the range of conditions and flow that will be seen in the POC pilot plant.

\subsection{ENGINEERING PROGRESS}

Overall the MK-F detail design effort is $95 \%$ through september 30 th. The engineering progress hy discinline fallows. 
Process Group:

Work continued on the process operation including plant restart after trips, the plant trip matrix, and the permissive interlocks.

The development of the start-up manual is continuing.

The J-valve designs were finalized based upon Dr. zenz's recommendations. The associated changes to the instrumentation were incorporated into the P\&ID drawings Revisions 3. The nitrogen system was changed to meet the increased flow in the J-valves.

Mechanical/Piping Group:

An acid-resistant coating was added to the lower section of the adsorber vessel $\mathrm{V}-101$.

The work package for Insulation subcontract in RFQ was issued in August.

The cyclone separator was released for purchase. Worked with Modern Welding to resolve changes to the regenerator $(\mathrm{V}-103)$. Released J-valve drawings for bid.

The piping engineering work is substantially complete.

Controls Group:

The major effort focused on the Bailey DCS configuration drawings. Forty-four drawings showing the external terminations to the Bailey system were issued. Work continued on the configuration drawings required to program the DIS system. The programming of the Bailey Network-90 distributed control system was completed. The DCS has been checked out at Bailey and is ready for shipment to the field. Rev-1 of the 45 loops drawings was issued for construction.

Electrical Group:

The electrical schematics, single line, analyzer and control building power plans were issued for construction. The heat trace plans and details for piping freeze protection were also issued in August. 
Civi, structural Group:

The structural steel fabrication details were reviewed and returned to the steel fabricator in early August. This completed the civil/structural effort.

Architectural Group:

Completed in previous quarter.

3.5 SUPPORT WORK BY NOXSO, W. R. GRACE, AND OHIO EDISON

Noxso Accomplishments:

Met with PEMM-Corp, and the Noxso team at Noxso office to discuss J-valve design. As a result of this meeting, Dr. Zenz completed the detailed design of each of the three J-valves in the POC and submitted the design to $M K-F$ on July $17 t h$.

Drafted and submitted test plan to PEMM-Corp. for second phase of cold modeling tests.

Prepared several panel layouts for Noxso gas monitoring system and began construction of panels. Designed and fabricated panels for POC monitoring system.

Met with MK-F and Grace in Cleveland to discuss POC materials of construction and review status of POC control system.

Developed sequence of steps in cold, and hot start-up with methane in regenerator in conjunction with MK-F engineers.

\subsection{CONSTRUCTION PROGRESS}

The civil work was completed in early september. The ductwork tie-ins to the Toronto station were also completed in september.

The structural steel was received the first week in september, and the tower erection was started. It was $50 \%$ complete on september 30th. Vessels $\mathrm{V}-101$ and $\mathrm{V}-106$ were also installed. 
The underground electrical conduit was installed, and the power feed to the transformer was pulled and terminated.

The control and analyzer trailers were received and set up in August.

The quotes for the insulation subcontract work were received and are being evaluated.

Permanent material received this quarter included ductwork (partial), piping (partial), cooling fan, instrumentation (partial), vessels V-101\& $v-106$.

\subsection{CONFERENCE PAPERS}

\subsubsection{Title:}

The Noxso POC Pilot Plant Advanced Flue Gas Clean-up Technology.

\section{Author:}

Robert L. Gilbert - Noxso Program Manager MK-Ferguson Company.

\section{Abstract:}

The MK-Ferguson Company is the engineering/construction member of a team that includes the Noxso Corporation as the technology developer; W.R. Grace \& Co-Conn as the sorbent supplier; and Ohio Edison as the owner of the host site. This ieam is working together to bring to commercial status the NOXSO simultaneous $\mathrm{SO}_{2} / \mathrm{NO}_{\mathrm{x}}$ Flue Gas Cleaning system.

The objective of this project is to demonstrate the potential for application of the NOXSO Flue Gas Treatment (FGT) technology to coal-fired utility boilers in the 1990s. To accomplish this, the Noxso team will design, construct, operate, and test a proof-of-concept (POC) scale Noxso test facility at Ohio Edison's Toronto Station, a coal-fired power plant. The pilot plant will process a 12,000-SCFM slip stream of flue gas from the power plant.

The goal of the POC test is to obtain the engineering data required to prepare a cost-effective design of a commercial-scale Noxso process module at an acceptable level of technical risk. A secondary goal of the test program is to optimize process performance, i.e., achieve $90 \%$ 
removal of $\mathrm{SO}_{2}$ and $\mathrm{NO}_{x}$ from the flue gas at the lowest possible cost, $x$ while maintaining the high level of system reliability required by the utilities market.

\subsection{Plans For Next Quarter}

4.1 Summary

The process equipment will be delivered to the site, as will the motor starter and the DCS system.

Task 2.5 Construction - See section 4.2 for detailed díscussion.

Task 2.6 startup - The sorbent material is being manufactured and is scheduled to be delivered to the site in the first quarter of 1991. The startup procedures and trip matrix work will continue, and the startup plan by Noxso will begin.

4.2 Task 2.5 CONSTRUCTION

Construction Activities by Major Task

Structural:

The subcontractor will complete erecting the structural steel tower, along with rough setting the process vessels. He also will erect the ductwork/pipe rack steel to allow the start of ductwork erection.

Process Equipment, Piping \& Ductwork:

The process vessels in the tower will be final set. The cooling air blower and adsorber feed fan will be set. Piping and ductwork will be completed inside the existing plant, along with the ductwork to the stack.

Electrical/Instrumentation:

The cable and tubing trays will be installed in the tower and to the control/analyzer trailers. Tower conduit and cable will be installed. lighting in the tower also will be completed. Delivery and calibration of the engineered instruments will begin. The DCs equipment will be installed in the control trailer. 
Insulation:

The insulation subcontract will be awarded in october. The subcontractor is scheduled to mobilize in November. Work will start on insulating the equipment and ductwork. 


\title{
THE NOXSO POC PILOT PLANT
}

\section{ADVANCED FLUE GAS CLEAN-UP TECHNOLOGY}

\author{
Robert L. Gilbert \\ NOXSO Program Manager \\ MK-Ferguson Company
}

\begin{abstract}
The MK-Ferguson Company is the engineering/construction member of a team that includes the NOXSO Corporation as the technology developer; W. R. Grace \& Co-Conn as the sorbent supplier; and Ohio Edison as the owner of the host site. This team is working together to bring to commercial status the NOXSO simultaneous $\mathrm{SO}_{2} / \mathrm{NO}_{\mathrm{x}}$ Flue Gas Cleaning System.
\end{abstract}

The objective of this project is to demonstrate the potential for application of the NOXSO Flue Gas Treatment (FGT) technology to coal-fired utility boilers in the 1990 s. To accomplish this, the NOXSO team will design, construct, operate, and test a proof-of-concept (POC) scale NOXSO test facility at Ohio Edison's Toronto Station, a coal-fired power plant. The pilot plant will process a 12,000-SCFM slip stream of flue gas from the power plant.

The goal of the POC test is to obtain the engineering data required to prepare a cost-effective design of a commercial-scale NOXSO process module at an acceptable level of technical risk. A secondary goal of the test program is to optimize process performance, i. e. , achieve $90 \%$ removal of $\mathrm{SO}_{2}$ and $\mathrm{NO}_{\mathrm{x}}$ from the fiue gas at the lowest possible cost, while maintaining the high level of system reliability required by the utilities market.

The project is a scale-up of previous laboratory tests.

\section{The NOXSO Process}

The NOXSO Process consists of two cycles: $\mathrm{SO}_{2}$ and $\mathrm{NO}_{x}$ adsorption and sorbent regeneration.

The flue gas $\mathrm{SO}_{2}$ and $\mathrm{NO}_{x}$ adsorption cycle is shown in Figure 1. The flue gas is directed to the NOXSO system after the particulate removal equipment via a booster fan. The flue gas is cooled to $230^{\circ} \mathrm{F}$ the optimum temperature for maximum $\mathrm{NO}_{x}$ and $\mathrm{SO}_{2}$ adsorption, and then passes through the adsorber contacting a fluidized bed of sorbent beads. The adsorption of $\mathrm{NO}_{x}$ and $\mathrm{SO}_{2}$ is a slightly exother-

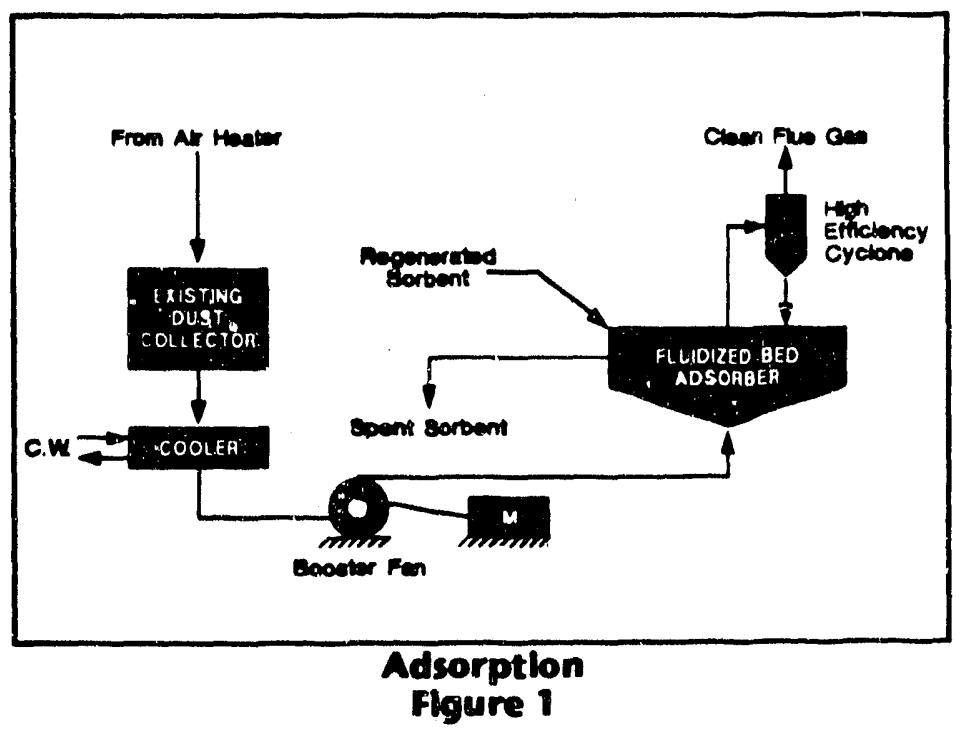


mic reaction which raises the flue gas temperature leaving the adsorber approximately $230^{\circ} \mathrm{F}$, thus eliminating the need for any reheat to maintain stack buoyancy.

To reduce sorbent entrainment, a high-efficiency mechanical cyclone collector is included in the flue gas loop just after leaving the adsorber. Entrained sorbent is captured by the cyclone and returned to the bed.

The sorbent beads are approximately 1.2 millimeters in diameter and consist of sodium carbonate deposited on a gamma-alumina substrate. The exact composition and process for manufacturing this sorbent is a patent held by NOXSO Corporation and licensed to the W. R. Grace Company for manufacture.

Spent sorbent is continuously removed from the top of the bed via an overflow weir and gravity fed to a pneumatic conveying system where it is conveyed to the regeneration cycle.

Figure 2 shows the regeneration cycle. The spent sorbent first enters a heating vessel which is a three-stage fluidized bed. The sorbent is heated with clean air to approximately $1200^{\circ} \mathrm{F}$. At this temperature, all of the $\mathrm{NO}_{\mathrm{x}}$ adsorbed in the sorbent is desorbed and carried off in the heated air steam and returned to the stack. In a commercial installation, the hot air and $\mathrm{NO}_{\mathbf{x}}$ from the sorbent heater is returned to the coal-fired boiler as combustion air io suppress the formation of $\mathrm{NO}_{\mathbf{x}}$ in the combustion process. The $\mathrm{NO}_{\mathrm{x}}$ recycle is not part of the NOXSO POC test.

The heated sorbent, containing adsorbed sulfur compounds, is then transported to the first regeneration vessel. In this vessel, the sorbent is treated with natural gas which produces a mixture of $\mathrm{SO}_{2}$ and $\mathrm{H}_{2} \mathrm{~S}$. The natural gas also reduces some adsorbed sulfur to $c_{\text {c sulfide }}$

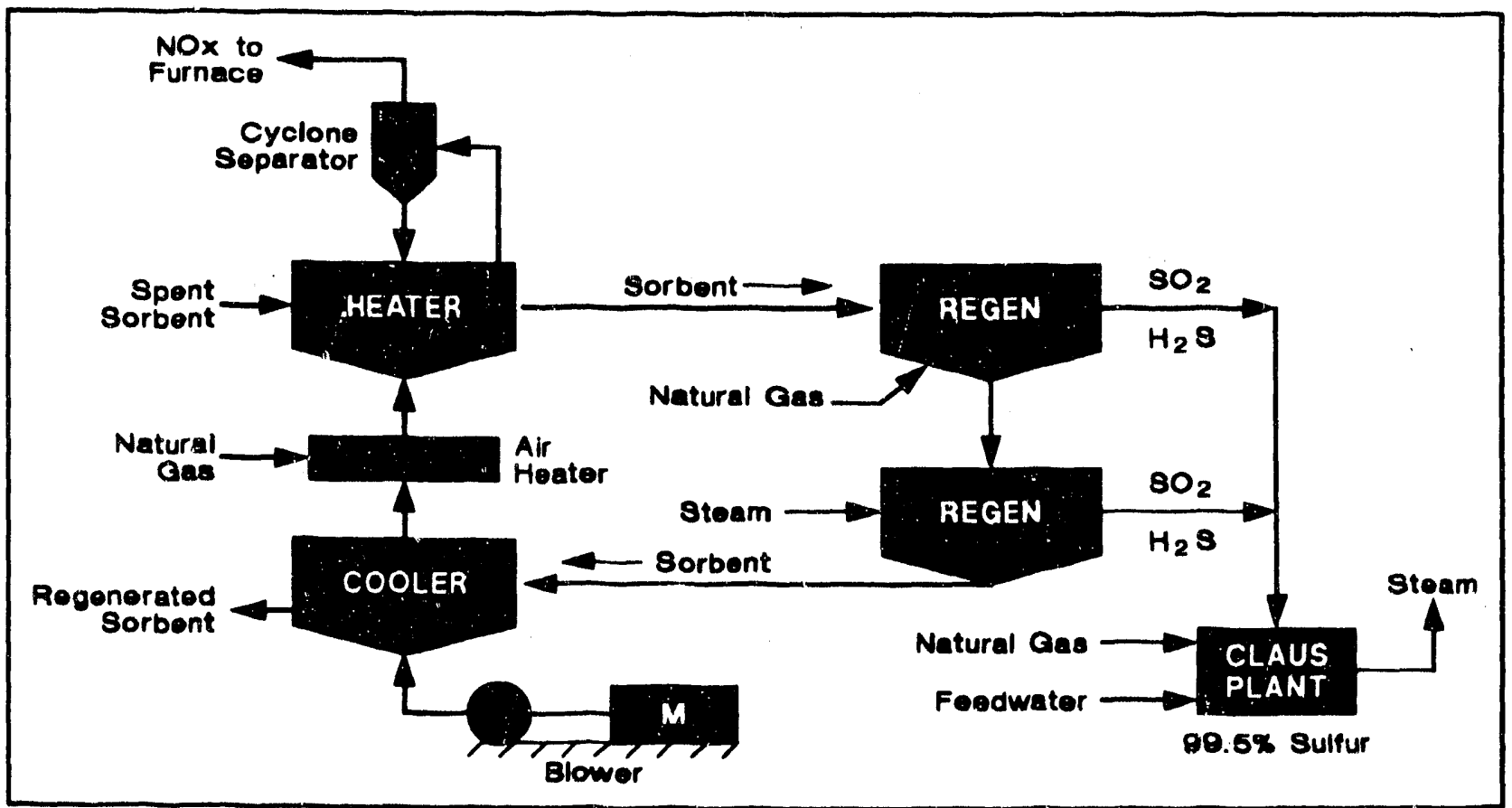

Regeneration

Figure 2 


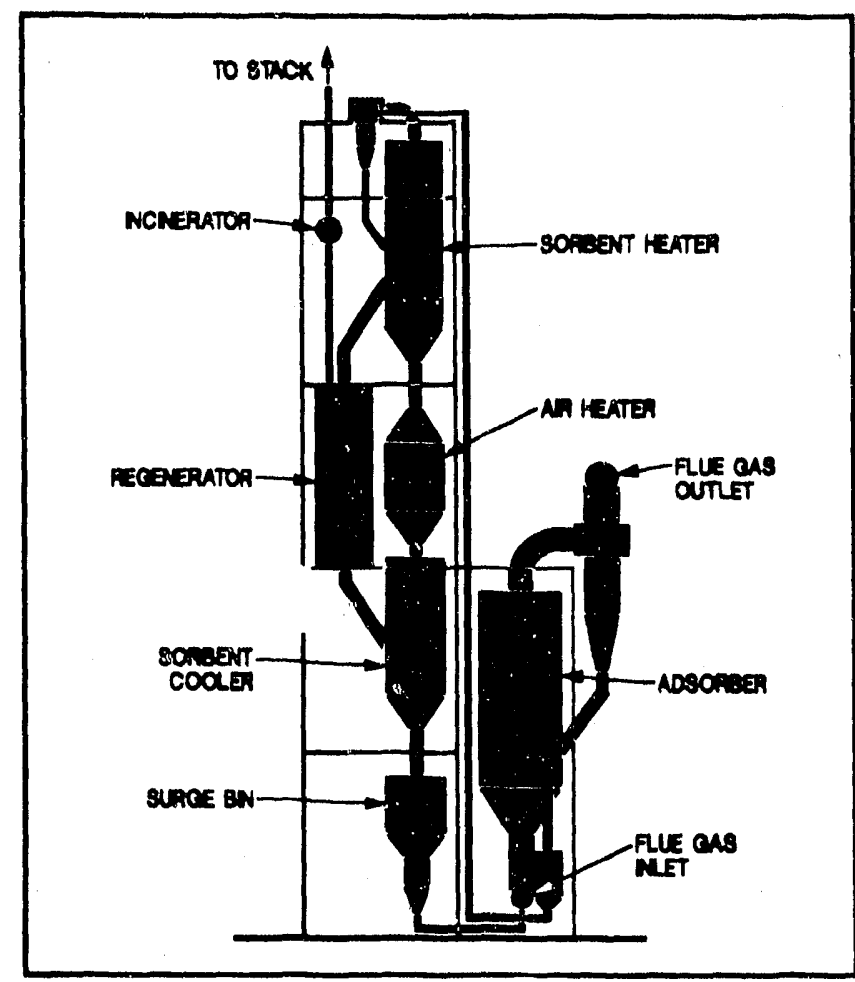

Poc Project Elevation

Figure 3 which remains on the sorbent. In a second regeneration step, the sorbent is treated with steam to hydrolyze the remaining sulfide to $\mathrm{H}_{2} \mathrm{~S}$. In a full-scale plant the mixture of $\mathrm{SO}_{2}$ and $\mathrm{H}_{2} \mathrm{~S}$ produced in the regenerator is sent to a Claus plant. Claus plants chemically convert the $\mathrm{SO}_{2}$ and $\mathrm{H}_{2} \mathrm{~S}$ to elemental sulfur and water. The Clous process is a well-developed technology and is not part of the POC test.

The regenerated sorbent is then transported to the sorbent cooler where it is cooled to $250^{\circ} \mathrm{F}$ with ambient air. The heated air leaving the sorbent cooler is used to heat the sorbent in the sorbent heater.

The NOXSO POC pilot plant process tower equipment general arrangement and site plan are shown in Figures 3 and 4 .

The NOXSO process tower is $22 \times 38$ feet and is about 72 feet high.

\section{Project Work Plan and Schedule}

The project is divided into six trsks. The purpose of Task 1 is to establish a work plan that details all the activities related to the successful completion of the project. Task 2 consists

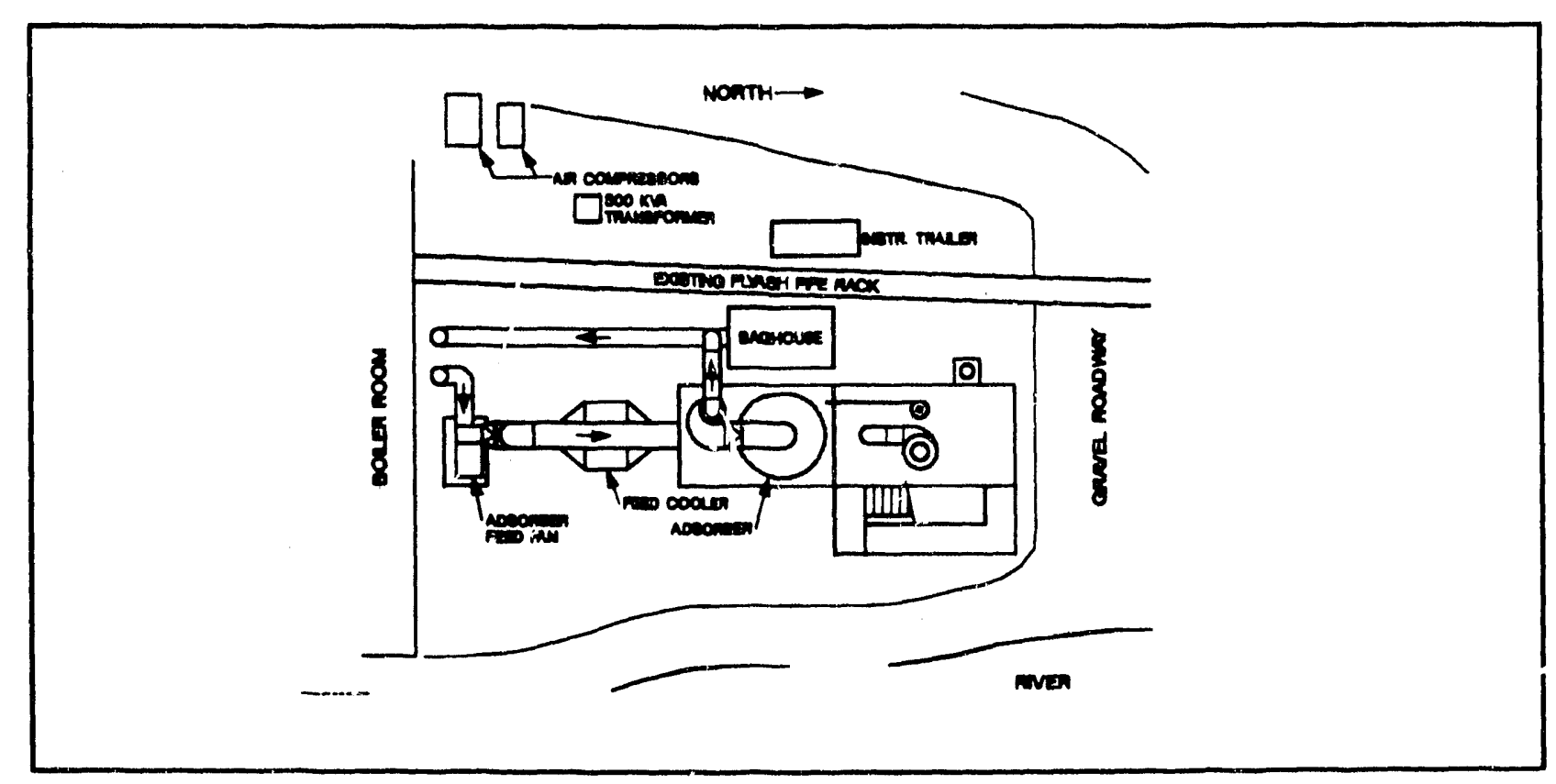




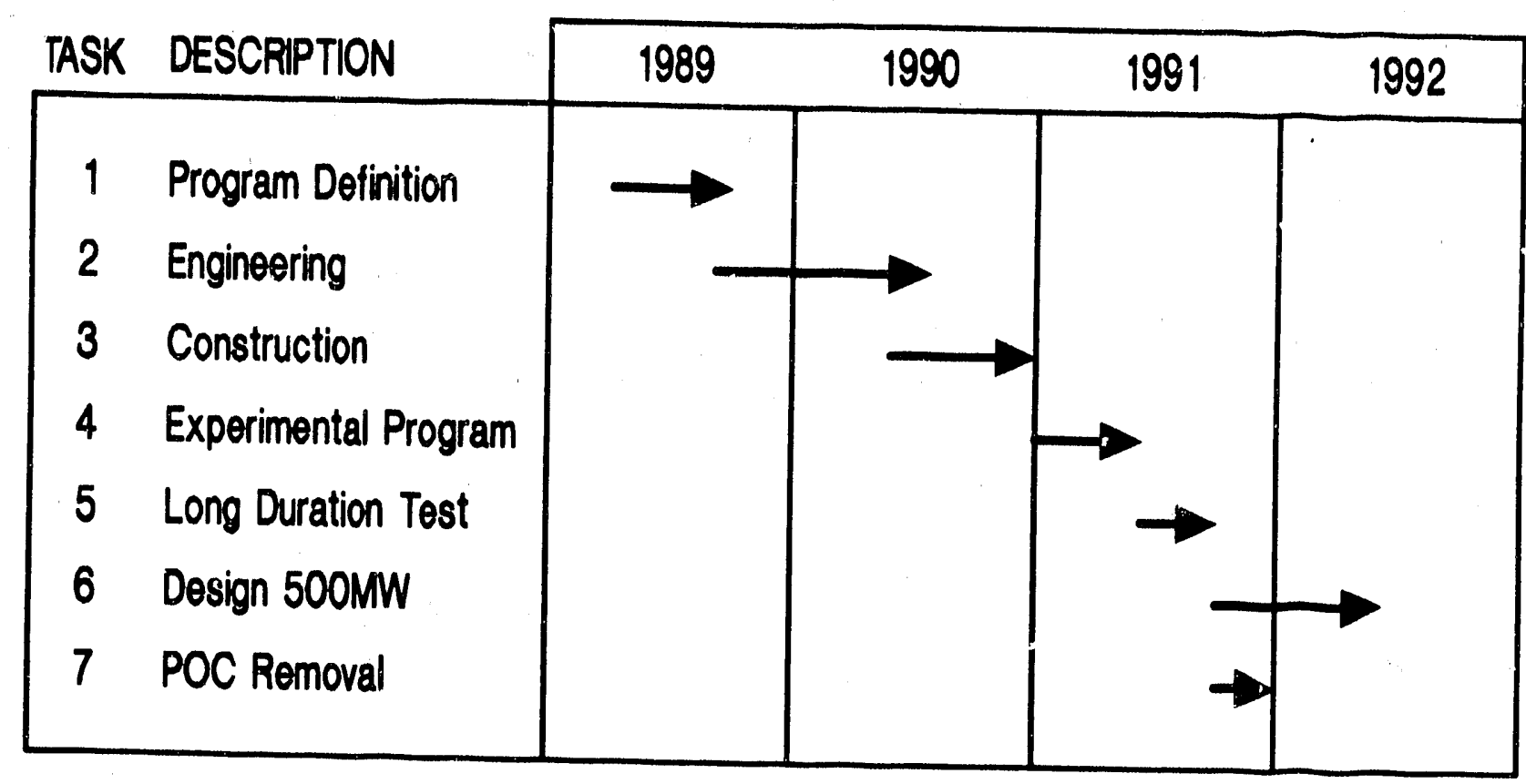

Poc Summary Schedule

Flgure 5

of the design and construction of the pilot plant. Task 3 consists of an experimental program to define both operating conditions and performance data to support Task 4 . Task 4 primary activities are to conduct a long duration test which attains continuous $90 \%$ sulfur dioxide and nitrogen oxide removal rates. Task 5 will be the conceptual design of a $500 \mathrm{MW}$ plant, including an economic evaluation of the conceptual design. Task 6 will be the demolition of the pilot plant and restoration of the site. The POC summary schedule is shown in Figure 5.

The following narrative describes the POC scope of work.

Task 1 Program Definition - Complete

This task entails submittal of the work plan which details all activities related tothe successful completion of the project. The major elements of the wirk plan include: - A 23-page narrative describing the technical approach taken to accomplish each of the
six tasks.

- A project schedule identifying the activities, their duration and logic to meet the planned project milestones.

- Project site access agreement with Ohio Edison.

- Process flow diagram and general arrangement drawings.

Task 1.1 Process Studies - In Progress

Process studies we re added to the scope of work to obtain additional information for Task 2.3 detailed engineering. 
The studies include dense phase sorbent conveying tests by equipment manufacturers and dynamic modeling tests of the fluid bed internals and J-valves. The dense phase conveying tests demonstrated that the sorbent could be conveyed pneumatically with minimal attrition. The dynamic modeling tests are on going with PEMM-Corp.

Task 2.1 Process Design Package - Complete

The PCC test facility was designed to treat 12,000 SCFM of flue gas containing approximately 2500 ppmd $\mathrm{SO}_{2}$ and 365 ppmd NOx. The POC test facility will integrate adsorption and regeneration process steps so that a continuous flow of sorbent goes from the adsorber to the sorbent heater to the regenerator to the sorbent cooler and back to the adsorber.

Task 2.2 Detailed Test Plan - Complete

The detailed test plan was prepared by NOXSO with support from W. R. Grace. It was approved by DOE on May 9, 1990.

The test plan consist of four parts:

1) Shakedown/Startup Tests

2) Baseline Tests

3) Parametric Tests

4) Long-Duration Tests

The test plan is briefly discussed later in the tasks covering the testing.

Task 2.3 Detailed Engineering - In Progress

The detailed engineering effort is broken into work packages. The engineering progress is as follows:

Civil: Site plan, grading and foundations: This work is complete except for incorporating the finalized vendor information.:

Structural: Main steel framing, platforms and miscellaneous steel: This work is complete except for incorporating the finalized vendor information.

Mechanical \& Plping: The equipment general arrangements have been finalized. The ductwork layout is in progress and the piping drawings have been started. The insulation scope will be established when the piping drawings are complete.

Process and Controls: The P\& ID drawings are complete. The instrument data sheets are being developed and RFQs are being written. The instrument loop diagrams have been starter.

Electrical: The power grounding and lighting drawings have been started. The schematics, conduit routing, wire routing will start when the controls work is complete. 
Task 2.4 Procureinent:

The major equipment purchase ordess have been issued. The remaining equipment includ. ing instrumentation, ductwork and alectrical items are out for bid.

Task 2.5 Construction:

The civil work started in June and will finish in August. The struciurai work will start in August and finish in September. The balance of the work will start in August and is planned to be completed in November of this year.

Tas: 2.6 Startup:

Shakedown/Startup Test: The purpo:e of the shakedown/ startup test is to ensure that the equipment operutes at design specifications prior to the start of the baseline test. In the shakedowm rost, each piece of equipment is checked out individually. The major pieces of equipment are the fluidized beds, reactors, blowers, flue gas cooling system, solids transport systems, incinerator, air heater, cyclones, and baghuuse. The performance of each major piece of equipment is quanified in the shakedown test.

Baseline Test: The baseline test operating parameters are derived from previous tests of the NOXSO process wis the IVA Shawnee Steam Plant and the Pittsburgh

Energy Technology Center (PETC). A performance model developed by W. R. Grace and based un data generated in previous tests of the NOXSO process was used to calculate the sorbent circulation rate in the POC baselinats test. The rnodel predicts $92 \% \mathrm{SO}_{2}$ removal and $85^{\circ} b$ NOx after 100 cycles of POC operation.

Task 3 - Parametric Tests:

The goal of the parametric tests is to identify the set of process operating conditions that result in optimum process performance. In the parametric tests, process operating conditions are systematically varied to quantify their affect on process performance.

Task 4 - Long Duration Tests:

The goal of the duration tests is to document long-term process performance under optimal process operating conditions. Optimal process operating conditions will be determined from the results of the parametric tests and will be maintained at constant values throughout the duration cesis. Process performance is evaluated in terms of process operating cost per weight of pollutant removed from the flue gas.

Task 5 - 500MW Design:

At the completion of the testing program MK-F will develop a 500MW conceptual design. Capital and operating costs will be forecas:ed based upon the 500MW design and the POC test results.

Task 6 - Demolition:

The pilot plant will be dismantled and the host site restored to pre-demonstration status. 

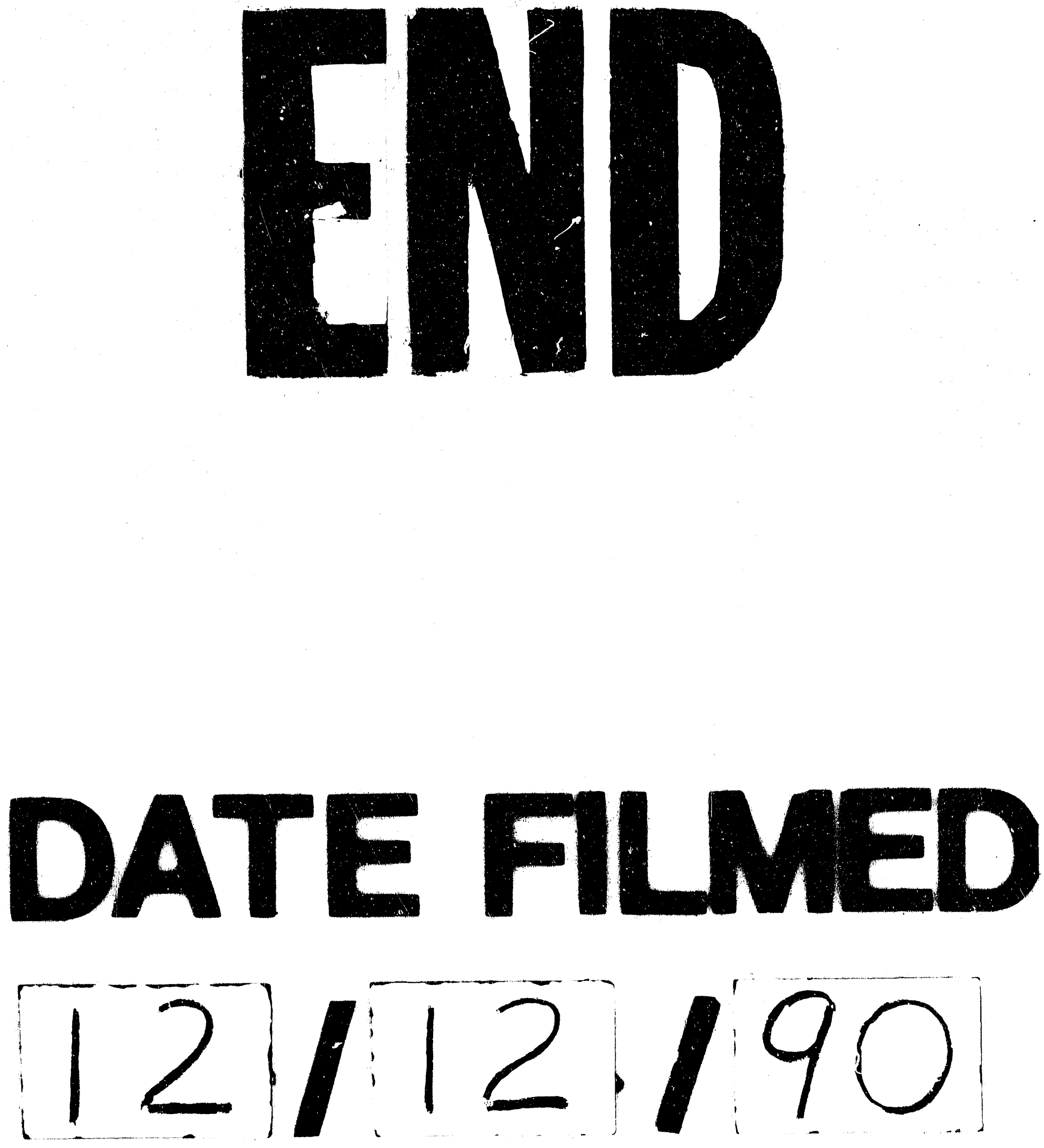
$=$ 